\title{
Osteogenesis and biofilms formation on titanium surfaces submitted to oxygen
}

\section{plasma immersion ion implantation}

\author{
Osteogênese e formação de biofillmes em superfícies de titânio submetidlas à implantação de íons \\ por imersão em plasma de oxigênio \\ Osteogénesis y formación de biofilms en superficies de titanio sometidas a implantación de iones \\ por inmersión en plasma de oxígeno
}

Received: 04/30/2021 | Reviewed: 05/09/2021 | Accept: 05/17/2021 | Published: 06/03/2021

\author{
Ítalo Rigotti Pereira Tini \\ ORCID: https://orcid.org/0000-0002-4902-6864 \\ Universidade Estadual Paulista, Brazil \\ E-mail: italo.tini@unesp.br \\ Juliani Caroline Ribeiro de Araújo \\ ORCID: https://orcid.org/0000-0001-6926-1581 \\ Universidade Estadual Paulista, Brazil \\ E-mail: julianicraraujo@hotmail.com \\ Thaís Fernanda Gonçalves \\ ORCID: https://orcid.org/0000-0002-8056-5217 \\ Universidade Estadual Paulista, Brazil \\ E-mail: thaisfernandag@hotmail.com \\ Rogério de Moraes Oliveira \\ ORCID: https://orcid.org/0000-0002-7112-521X \\ National Institute for Space Research, Brazil \\ E-mail: rogerio.oliveira@inpe.br \\ Danieli Aparecida Pereira Reis \\ ORCID: https://orcid.org/0000-0002-1871-6475 \\ Universidade Federal de São Paulo, Brazil \\ E-mail: danieli.reis@unifesp,br \\ Adriano Gonçalves dos Reis \\ ORCID: https://orcid.org/0000-0001-6465-4538 \\ Universidade Estadual Paulista, Brazil \\ E-mail: adriano.reis@unesp.br \\ Luana Marotta Reis de Vasconcellos \\ ORCID: https://orcid.org/0000-0003-4344-0578 \\ Universidade Estadual Paulista, Brazil \\ E-mail: luana.marotta@unesp.br
}

\begin{abstract}
The objectives of this study were to characterize titanium (Ti) surfaces treated by ion implantation by immersion in oxygen plasma (O-PIII) at different temperatures, correlating these implanted layers with therapeutic effects and with osteogenesis, as well as the formation of monotypic biofilms microbial. The groups were divided into: a) Ti (pretreatment) b) $\mathrm{Ti} \mathrm{O}-\mathrm{PIII}$ at $400^{\circ} \mathrm{C}$. c) Ti O-PIII at $500^{\circ} \mathrm{C}$. d) Ti O-PIII at $600^{\circ} \mathrm{C}$. The properties and surface characteristics were evaluated according to the roughness, texture, corrosion resistance, formation of new phases and the identification of chemical compounds present. Cellular analyzes investigated cell interaction, viability, total protein content, alkaline phosphatase and quantification of mineralized nodules using MG-63 cells. The formation of monotypic microbial biofilms, including P. aeruginosa, S. aureus, S. mutans and C. albicans were evaluated. The increase in surface roughness, corrosion resistance and oxygen content, leading to the formation of $\mathrm{TiO}_{2}$-rutile with more intense peaks and in greater numbers according to the increase in the substrate temperature, ionic implanted Ti samples was observed. There was also a significant increase in cell viability, total protein production, alkaline phosphatase activity and formation of mineralization nodules for the group treated with $\mathrm{O}-\mathrm{PIII}$ at $600^{\circ} \mathrm{C}$ compared to other groups, in addition to a reduction of microorganisms in the groups treated with O- PIII. Therefore, treatment with O-PIII at $600^{\circ} \mathrm{C}$ in Ti grade IV showed favorable results for its use.
\end{abstract}

Keywords: Osteogenesis; Biocompatibility; O-PIII; Biofilm; Titanium alloy.

\section{Resumo}

Os objetivos deste estudo foram caracterizar superfícies de titânio (Ti) tratadas por implantação de íons por imersão em plasma de oxigênio (O-PIII) em distintas temperaturas, correlacionando tais camadas implantadas com efeitos 
terapêuticos e com osteogênese, bem como a formação de biofilmes monotípicos microbianos. Os grupos foram divididos em: a) Ti (pré-tratamento) b) Ti O-PIII a $400^{\circ}$ C. c) Ti O-PIII a $500^{\circ}$ C. d) Ti O-PIII a $600{ }^{\circ}$ C. As propriedades e características superficiais foram avaliadas de acordo com a rugosidade, textura, resistência à corrosão, formação de novas fases e a identificação de compostos químicos presentes. As análises celulares investigaram a interação celular, viabilidade, conteúdo de proteína total, fosfatase alcalina e quantificação de nódulos mineralizados usando células MG-63. A formação de biofilmes microbianos monotípicos, incluindo P. aeruginosa, S. aureus, $S$. mutans e $C$. albicans foram avaliadas. $\mathrm{O}$ aumento da rugosidade superficial, da resistência à corrosão e do teor de oxigênio, levando à formação de $\mathrm{TiO}_{2}$-rutilo com picos mais intensos e em maior número de acordo com o aumento da temperatura do substrato amostras de Ti implantadas iônicas foi observado. Houve também aumento significativo na viabilidade celular, produção de proteína total, atividade da fosfatase alcalina e formação de nódulos de mineralização para o grupo tratado com O-PIII a $600^{\circ} \mathrm{C}$ em comparação com outros grupos, além de redução de microrganismos nos grupos tratados com O-PIII. Portanto, o tratamento com O-PIII a $600^{\circ} \mathrm{C}$ em Ti grau IV apresentou resultados favoráveis para sua utilização.

Palavras-chave: Osteogênese; Biocompatibilidade; O-PIII; Biofilme; Liga de titânio.

\section{Resumen}

Los objetivos de este estudio fueron caracterizar superficies de titanio (Ti) tratadas mediante implantación de iones por inmersión en plasma de oxígeno (O-PIII) a diferentes temperaturas, correlacionando estas capas implantadas con efectos terapéuticos y con osteogénesis, así como la formación de biofilms monotípicos microbianos. Los grupos se dividieron en: a) Ti (pretratamiento) b) Ti O-PIII a $400^{\circ} \mathrm{C}$ c) Ti O-PIII a $500^{\circ} \mathrm{C}$ d) $\mathrm{Ti} \mathrm{O}$-PIII a $600{ }^{\circ} \mathrm{C}$. Las propiedades y se evaluaron las características superficiales según rugosidad, textura, resistencia a la corrosión, formación de nuevas fases e identificación de compuestos químicos presentes. Los análisis celulares investigaron la interacción celular, la viabilidad, el contenido total de proteínas, la fosfatasa alcalina y la cuantificación de nódulos mineralizados utilizando células MG-63. Se evaluó la formación de biofilms microbianos monotípicos, incluidas $P$. aeruginosa, $S$. aureus, $S$. mutans y C. albicans. Se observó el aumento de la rugosidad superficial, la resistencia a la corrosión y el contenido de oxígeno, lo que dio lugar a la formación de $\mathrm{TiO}_{2}$-rutilo con picos más intensos y en mayor número según el aumento de la temperatura del sustrato, se observaron muestras de Ti implantado iónico. También hubo un aumento significativo de la viabilidad celular, producción total de proteínas, actividad de la fosfatasa alcalina y formación de nódulos de mineralización para el grupo tratado con O-PIII a $600^{\circ} \mathrm{C}$ en comparación con otros grupos, además de una reducción de microorganismos en los grupos tratados con O - PIII. Por tanto, el tratamiento con O-PIII a $600^{\circ} \mathrm{C}$ em Ti grado IV mostró resultados favorables para su uso.

Palabras clave: Osteogénesis; Biocompatibilidad; O-PIII; Biofilms; Aleación de titanio.

\section{Introduction}

Titanium (Ti) stands out as a material of interest for orthopedics and dentistry due to a range of outstanding characteristics such as biocompatibility, easy manipulation, high corrosion resistance, high modulus of elasticity, accessible acquisition and affordability (Gimmel'farb, \&Abrarov 1980, Thelen et al.,2004; Simdabe, 2014). Ti implants should remain in the human body for a long time and bear the same loads as the surrounding bone, so it is important that these implants not only allow osseointegration, but also present mechanical characteristics similar to bone tissue. Although the widespread use of Ti for the implant area, intense investigation efforts have been carried out in order to optimize the properties of the implanted surfaces for a rapid and adequate biofixation (Kohavi et al.,2013). When Ti is exposed to atmospheric air, a thin passivating layer of native Ti oxide is formed, which facilitates biocompatibility (Yamagami et al.,2014). However, it can be rapidly destroyed by relative movements and friction between the implant and the tissue (Mandl et al., 2001). Because of these frictions, Ti particles can be locally deposited and further transported to gingiva, lung and spleen, possibly causing sequelae (Mandl et al., 2001, Guglielmotti et al., 2015, Heringa et al., 2018). Long-term effects may cause distinct issues, such as loss of the implant itself, often resulting in prosthetic corrective surgeries. In this context, it is essential to evaluate interactions between osteoblastic cells and the biomaterial.

Among several surface treatment proposed for Ti implants (Munoz-Castro et al.,2009, Valencia-Alvarado et al., 2010, Xiao et al., 2012) oxygen ion implantation represents an effective tool, capable of changing morphology, composition and crystalline phase, as well as mechanical and tribological properties (Oliveira et al., 2011, Savonov et al., 2011; Da Silva et al., 2006, Peláez-Abellán et al., 2012). In addition, it has been previously demonstrated that O-PIII treatment improves 
osseointegration in rat femurs after 3 months of incubation when compared to untreated Ti implants (Mandl et al., 2001; Mandl et al., 2002). Yang et al. (2015) demonstrated that O-PIII treated Ti provides better protein adsorption, adhesion, migration, proliferation, mineralization and differentiation of hMSCs (mesenchymal stem cells), indicating that an appropriate treatment with O-PIII may improve the biocompatibility and functionality of Ti surface.

Several characteristics of the implants, including surface composition, topography, hydrophobicity, load, microstructure and flexibility influence bacterial adhesion and biofilm formation (Morais et al., 2013, Do Prado et al., 2013). Implant-related infections are considered the most serious complication common to the risk of surgical infection, which increases when foreign material is implanted. Biomaterial-associated infections are challenging to treat, since bacteria in the biofilm are protected by the host immune system. Moreover, ineffective antibiotics represent another consistent obstacle (Zhao et al., 2015). Highly resistant bacterial strains, contamination of the surgical area and the surrounding tissue endanger the health of the patients, affecting the osseointegration (Zhao et al., 2015, Zaatreh et al., 2016).

The objectives of this study were the characterization of O-PIII-treated Ti surfaces, the association between the materials and osteogenesis (in vitro) and the formation of monotypic microbial biofilms on the surface of the materials.

\section{Methods}

\subsection{Samples preparation and characterization}

A Grade-4 Ti ingot was machined into disks (12.7 $\mathrm{mm}$ in diameter and $3 \mathrm{~mm}$ thick) and used as the substrate. Prior to oxygen PIII treatment, the specimens were ultrasonically cleaned with acetone for $20 \mathrm{~min}$, and then dried in air.

Samples were treated in a high temperature PIII reactor (Oliveira et al., 2010) by performing the heating of the substrates at controlled temperatures simultaneously with the ion implantation. Thus, three set of samples were immersed in oxygen plasma for $1 \mathrm{~h}$, being individually treated under the same operational conditions: at 3x10-3 Torr, with pulses of $7.7 \mathrm{kV} / 30 \mu \mathrm{s} / 420 \mathrm{~Hz}$. Substrate temperature was the distinct parameter between the three groups (Group 1: Ti O-PIII at $400^{\circ} \mathrm{C}$; Group 2: Ti O-PIII at $500^{\circ} \mathrm{C}$; Group 3: Ti O-PIII at $600^{\circ} \mathrm{C}$ ). Group 4 corresponds to untreated titanium.

Quantitative analysis of oxygen content present on the surface of the samples was performed by EDS (Energy dispersive $\mathrm{X}$-ray spectrometry, Bruker, model XFlash Detector 410-M). The formation of new phases was confirmed by X-ray diffraction (XRD) with a diffractometer (Panalytical, model X'PERT POWER), $\mathrm{CuK} \alpha$ radiation source ( $\lambda=1,5406 \AA$ ), angular range at $2 \theta$ varied from $35^{\circ}$ to $90^{\circ}$. Measurements were performed at room temperature, in continuous scan mode, with a speed of $1.2^{\circ}$ per minute and an angular step of $0.02^{\circ}$. Voltage and electric current used were $45 \mathrm{kV}$ and $40 \mathrm{~mA}$, respectively. The identification of the diffracted peaks was done with the help of X'Pert Highscore software, provided by PANalytical BV, taking into account the JCPDS (Joint Committee on Powder Diffraction Standards) database.

The topography of the samples was evaluated by Atomic Force Microscopy using a Veeco equipment, model MULTIMODE V. An area of $2 \times 2 \mu \mathrm{m}$ of each sample was probed, using the Flex-Axiom MFA system.

Corrosion resistance of the samples and the effects of O-PIII treatments, in relation to the chemical treatment, was evaluated at chemical level, through the EIS (Electrochemical Impedance Spectroscopy) test.

For electrochemical analysis a three electrode cell was used, with $\mathrm{Ag} / \mathrm{AgCl}$ as the reference electrode, a platinum wire as the counter electrode and the Ti sample as the working electrode. Tests were performed in simulated body fluid (SBF) solution. EIS analyzes were performed with a $10 \mathrm{mV}$ disturbance signal amplitude, in the range between 105 and 10-2 Hz. Measurements were calculated after $0,2,4,8,12 \mathrm{~h}$ of submersion. Autolab (Metrohm, 302N) was used to evaluate the samples. In order to verify possible microstructural changes resulting from the corrosion tests, the corroded surfaces were examined by scanning electron microscopy (SEM, FEI Inspect S50 model). 


\subsection{In vitro cellular analyzes}

MG-63 cell line (Human Osteoblasts) from the cell bank of the Paul Ehrlich Scientific Technical Association (APABCAM, Rio de Janeiro, Brazil) was used. Cells were cultivated with Dulbecco's Modified Eagle's Medium (DMEM) (Cultilab, Campinas, Brazil) supplemented with 10\% Fetal Bovine Serum (FBS) (Cultilab, Campinas, Brazil), penicillin (100 U $/ \mathrm{mL})$ and streptomycin $(100 \mu \mathrm{g} / \mathrm{mL})$ (Cultilab, Campinas, Brazil). All tests were developed in accordance with ISO-10993-5 and described by Andrade et al. (2015) and Prado et al. (2018).

Cell interaction with the materials was evaluated by SEM after seven days of incubation $(n=02)$. Cells were fixed with paraformaldehyde (4\%) at room temperature, dehydrated through an ascending series of ethanol $(70 \%, 90 \%$ and $100 \%)$ and, prior to the analysis, all samples were coated with a thin layer of gold, using a sputter-coating system (Emitech, model SC7620). The equipment used was the Inspect S50 model of the FEI brand (Thermo Fisher Scientific, Massachusetts, USA).

Cells were incubated in contact with the materials for 3 days, thereafter cell viability was quantified by exposing the cells to the toxic agent by incubation with the MTT dye (3-(4,5-dimethylthiazol-2-yl)-2,5-diphenyltetrazolium bromide) (SigmaAldrich, Saint Louis, USA) at a concentration of $0.5 \mathrm{mg} / \mathrm{mL}$. After $1 \mathrm{~h}$ of incubation, at $37{ }^{\circ} \mathrm{C}$ and $5 \% \mathrm{CO}_{2}$, the organic solvent DMSO (Dimethylsulfoxide) (Sigma-Aldrich, Saint Louis, USA) was added to solubilize the formazan crystals. For each experimental group, $\mathrm{n}=05$ was determined. Colorimetric microplate reader was used at wavelength $570 \mathrm{~nm}$ (Biotek, model ELx808cse).

After being platted and cultivated for 10 days ( $\mathrm{n}=05$ per group), total protein content was calculated, according to the modified method of Lowry et al. (1951). For protein extraction, sodium surfactant lauryl sulfate (Sigma-Aldrich, Saint Louis, USA) at $0.1 \%$ was used. The solution was mixed with Lowry reagent (Sigma-Aldrich, Saint Louis, USA), at room temperature. Then, Folin-Ciocalteau reagent (Sigma-Aldrich, Saint Louis, USA) was added to the mixture. A spectrophotometer (Micronal, model AJX 1900) at $680 \mathrm{~nm}$ was used to calculate the absorbance and the total protein content was measured from a standard curve from bovine albumin pre-determined and expressed as $\mu \mathrm{g} / \mathrm{ml}$ unit.

After ten days of cell culture, alkaline phosphatase activity was analyzed and, for each experimental group, $n=05$ was considered. Thymolphthalein monophosphate and diethanolamine buffer $(0.3 \mathrm{M}$ and $\mathrm{pH} 10.1)$ substrates were added in glass tubes. To this solution, an aliquot of the lysates from each well was added, samples were maintained at $37^{\circ} \mathrm{C}$. Then, $\mathrm{Na} 2 \mathrm{CO} 3$ $(0.09 \mathrm{M})$ and $\mathrm{NaOH}(0.25 \mathrm{M})$ solutions were added to the tubes. Absorbance was calculated on a spectrophotometer (Micronal, model AJX 1900), at $590 \mathrm{~nm}$.

After a period of fourteen days of incubation ( $n=05$ for each experimental group), mineralized nodules were quantified. Hank's solution (H6136 - Sigma-Aldrich, Saint Louis, USA) was used for cell culture nutrition, in addition to Alizarin S red dye (Sigma-Aldrich, Saint Louis, USA), at a concentration of $2 \mathrm{mg} / \mathrm{ml}$, responsible for staining calcified areas. After one day, acetic acid (10\%) solvent was added, contents were transferred to centrifuge micro tubes (Sigma-Aldrich, Saint Louis, USA) and vortexed (Vortex, model QL 901). Samples were then centrifuged for 20 minutes and the supernatants were transferred to 96well plate (Thermo Fisher Scientific, Rochester, NY, USA). Reading was performed using a microplate reader (Biotek, model ELx808 IU), under the wavelength of $405 \mathrm{~nm}$.

\subsection{Microbial biofilm formation analysis}

Strains were used as reference (ATCC - American Type Culture Collection) of Pseudomonas aeruginosa (ATCC 15442), Staphylococcus aureus (ATCC 6538), Streptococcus mutans (ATCC 3I5688) and Candida albicans (ATCC 18804). BHI (Brain heart infusion) medium (Himedia, Mumbai, Maharashtra, India) was used for culturing the microorganisms, except for S. mutans, which requires saccharated BHI liquid medium. For monotypic biofilms formation, samples were distributed in 24well microplates (TPP Techno Plastic Products, Trasadigen, Switzerland) ( $\mathrm{n}=5$ for each experimental group) (Ti, Ti O-PIII at 
$500^{\circ} \mathrm{C}$ and Ti O-PIII at $600^{\circ} \mathrm{C}$, and the control group: empty well). Each microbial suspension was standardized in culture medium (BHI or saccharated BHI).

After a one-day incubation period, MTT (3- (4,5-dimethylthiazol-2-yl) -2,5-diphenyltetrazolium bromide) (SigmaAldrich, Saint Louis, USA) dye was added at a concentration of $0.5 \mathrm{mg} / \mathrm{ml}$. After incubation under light protection, the solution was removed, DMSO (Sigma-Aldrich, Saint Louis, USA was added and kept under stirring, in an orbital table. aliquots of 100 $\mu l$ of each well were transferred To 96-well plate (Thermo Fisher Scientific, Rochester, NY, USA). Absorbance reading was performed by a microplate reader (Biotek, model ELx808cse), at a wavelength of $570 \mathrm{~nm}$.

These procedures were performed as described by Mello et al. (2019).

\subsection{Statistical analysis}

Quantitative data of the results were statistically analyzed by GraphPad Prism 6 software, using one-way ANOVA and Tukey's multiple comparison tests. The level of significance adopted was the conventional value of $5 \%, 0.1 \%$ or $0.001 \%$.

\section{Results}

\subsection{Surface characterization}

According to Figure 1, Ti group (pretreatment) presented, comparatively, low amount of $\mathrm{O}$ on their surface $(6.94 \% \mathrm{O})$, while O-PIII-treated Ti groups at $400^{\circ} \mathrm{C}, 500^{\circ} \mathrm{C}$ and $600^{\circ} \mathrm{C}$ presented the mean values of $26.31 \%, 45.66 \%$ and $56.61 \%$ of $\mathrm{O}$, respectively, demonstrating that the higher the temperature reached in the PIII treatment, the greater the atomic percentage of $\mathrm{O}$ on the surface. In fact, the reactivity of the metal for oxygen uptake is increased with the temperature. The mechanism involves the dissolution of oxygen in the metal and its absorption. In addition, the oxygen ions implanted on Ti surface can reach deeper layers at higher temperatures due to diffusion process. The oxidation at high temperatures also promotes the development of crystalline phases.

Figure 1 - Surface analysis by dispersive energy spectroscopy in the following groups: Ti, Ti O-PIII at $400^{\circ} \mathrm{C}$, Ti O-PIII at $500^{\circ} \mathrm{C}$ and Ti O-PIII at $600^{\circ} \mathrm{C}$. Dispersive energy spectroscopy. $* * \mathrm{p}<0.05$, *** $\mathrm{p}<0.001$ and $* * * * \mathrm{p}<0.0001$ compared to Ti $*$ group (ANOVA and Tukey test). Asterisks indicates a statistical difference.

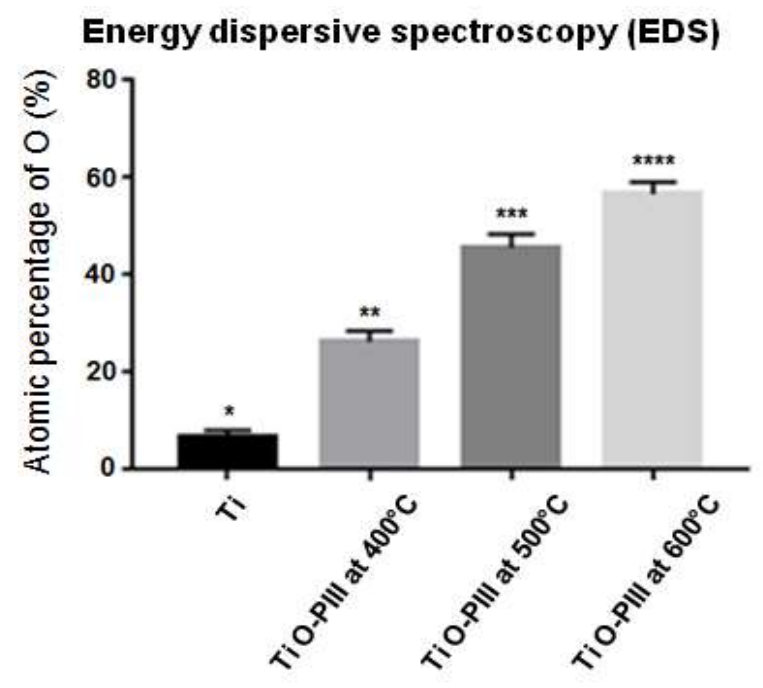

Source:Authors. 
Figure 2 shows the presence of $\mathrm{TiO}_{2}$ (rutile phase) peaks in the O-PIII-treated groups at $500^{\circ} \mathrm{C}$ and $600^{\circ} \mathrm{C}$, characterized mainly at the angle of $27.5^{\circ}$, considering the most intense peak of this phase. The presence of this peak was not identified in Ti (pretreatment) and Ti O-PIII groups at $400^{\circ} \mathrm{C}$. In fact, a consequence of the increase of the substrate temperature during PIII is the facilitation for the formation of the rutile phase, as observed in figure 2, due to the increase of the ratio of $\mathrm{O}$ to Ti. The presence of Ti- $\alpha$ had also been observed in all groups.

Figure 2 - Surface analysis by X-ray diffraction in the following groups: $\mathrm{Ti}$, Ti O-PIII at $400^{\circ} \mathrm{C}$, Ti O-PIII at $500^{\circ} \mathrm{C}$ and $\mathrm{Ti} \mathrm{O}-$ $\mathrm{PIII}$ at $600^{\circ} \mathrm{C}$. $\mathrm{Ti}(\bullet)$ and $\mathrm{TiO}_{2}$ rule $(\square)$.

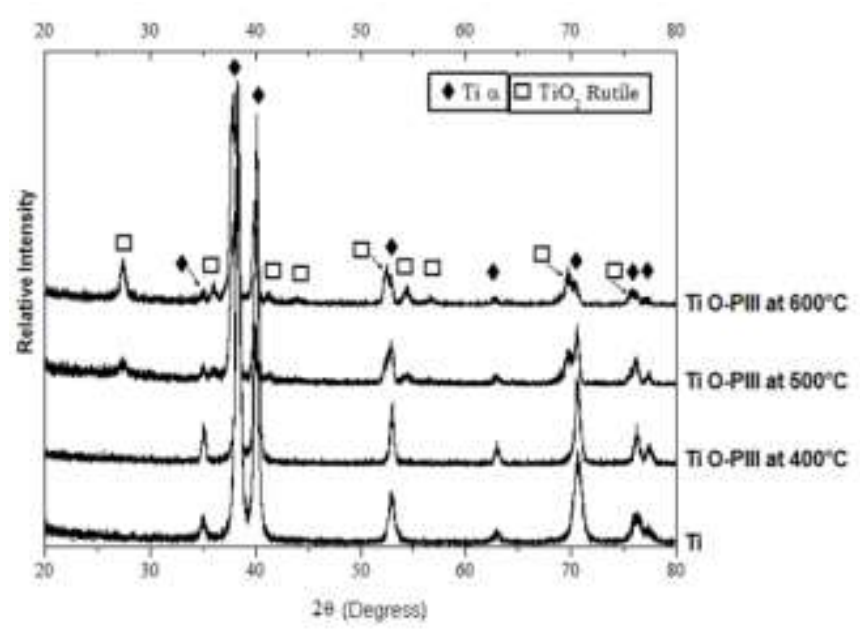

Source:Authors.

Ti (pretreatment) group exhibited relatively flat surfaces with traces of machining marks, as shown in Figure 3 (a). OPIII-treated samples exhibited nanometric structures on the surface, indicating a nanostructured $\mathrm{TiO}_{2}$ layer (in the form of round grains), as shown in Fig. 3 (b, c and d). According to our results, the higher the temperature reached in the O-PIII-treatment, a more numerous of such structures is observed. Figure 4 shows the roughness (RMS - Root mean square) and surface area profile values, confirming that increasing the O-PIII temperature, higher the RMS and the surface area. Figure 5 shows that Ti (pretreatment) sample, compared to the other O-PIII-treated Ti samples, had the lowest impedance in all evaluated frequencies, of almost one order of magnitude lower. This is an indication that the oxygen enriched modified surface layer produced via OPIII protects the metal surface from corrosion in SBF medium. O-PIII-treated Ti sample at $600^{\circ} \mathrm{C}$ was the one with highest impedance at medium frequency. At low frequencies, impedance was not differentiated between samples. 
Figure 3 - Surface analysis by atomic force microscopy (MFA-3D) in the following groups: a) Ti. b) $\mathrm{Ti} \mathrm{O}-\mathrm{PIII}$ at $400^{\circ} \mathrm{C}$. c) $\mathrm{Ti}$ O-PIII at $500^{\circ} \mathrm{C}$. d) $\mathrm{Ti} \mathrm{O}-\mathrm{PIII}$ at $600^{\circ} \mathrm{C}$.

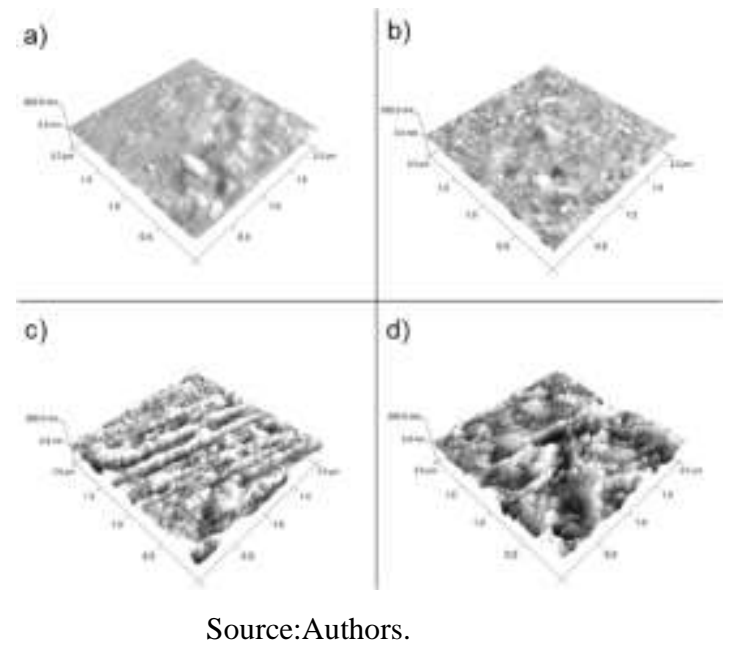

Figure 4 - Impedance module after $12 \mathrm{~h}$ of immersion, in the following groups: $\mathrm{Ti}$, Ti O-PIII at $400^{\circ} \mathrm{C}$, Ti O-PIII at $500^{\circ} \mathrm{C}$ and Ti O-PIII at $600^{\circ} \mathrm{C}$. Surface roughness ( $)$ and Surface area increase $(\bigcirc)$ ).

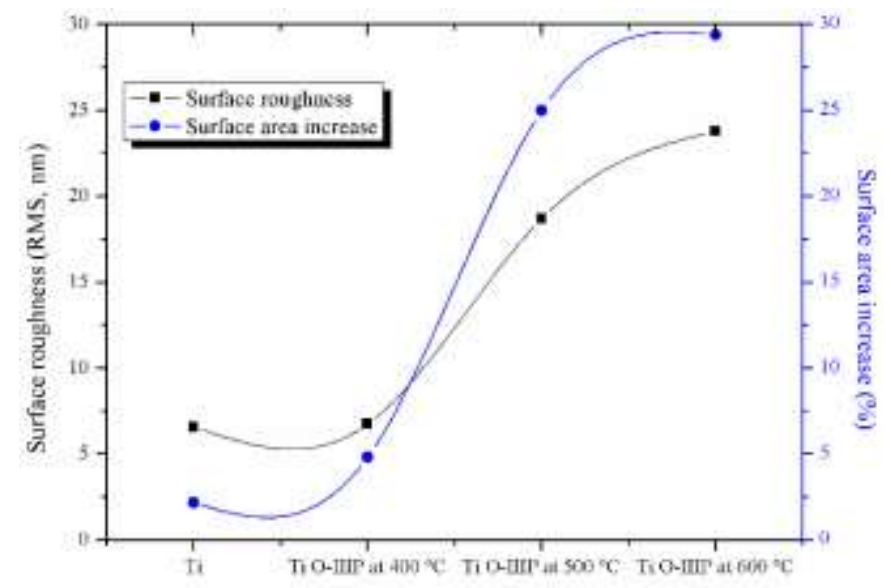

Source:Authors. 
Figure 5 - Impedance evaluated frequencies Ti (pretreatment) sample $\boldsymbol{\square}$ ) compared to the other O-PIII-treated Ti sample in the following groups: Ti O-PIII at $400^{\circ} \mathrm{C}(\bigcirc)$, Ti O-PIII at $500^{\circ} \mathrm{C}(\Delta)$ and Ti O-PIII at $600^{\circ} \mathrm{C}(\nabla)$.

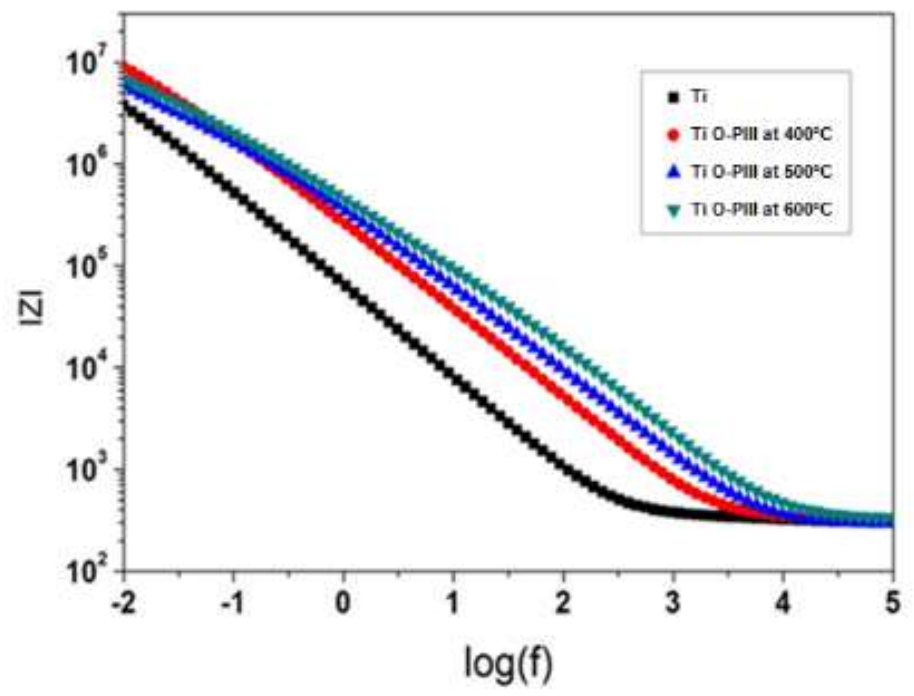

Source:Authors.

Additional investigation about the corrosion of the surfaces was performed by examining the topography of the surfaces. Figure 6 (a) demonstrates a well-defined corrosion site on the surface of Ti sample (pretreatment) as a consequence of SBF exposure. In Figure 6 (b, c and d), no specific corrosive sites were identified, only specific areas were observed, due to the production process of the samples.

Figure 6 - Photomicrographs obtained by scanning electron microscopy (SEM) of the following groups: a) Ti. b) Ti O-PIII at $400^{\circ} \mathrm{C}$. c) Ti O-PIII at $500^{\circ} \mathrm{C}$. d) Ti O-PIII at $600^{\circ} \mathrm{C}$. $(15,000 \mathrm{x})$. Arrow: Corrosion point on the sample surface $(\square)$.

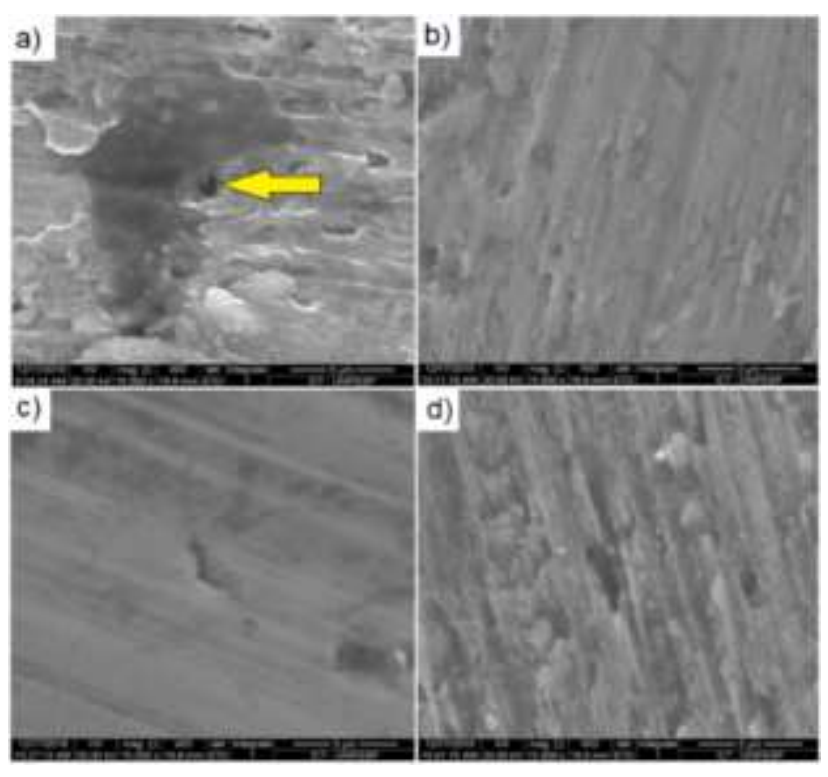

Source:Authors. 


\subsection{In vitro cell assays}

The cell morphology can be seen in Figure 7 (a) for untreated Ti sample and in Figure 7 (b, c, d) for O-PIII samples treated at $400^{\circ} \mathrm{C}, 500^{\circ} \mathrm{C}$ and $600^{\circ} \mathrm{C}$, respectively. In general, all samples allowed cell spreading. We suggest that samples submitted to O-PIII treatment had more evident cell adhesion, as cell prolongations were better observed in these treated groups.

Figure 7 - Photomicrograph obtained by SEM of MG-63 cells, surface interaction: a) Ti. b) Ti O-PIII at $400^{\circ} \mathrm{C}$. c) Ti O-PIII at $500^{\circ} \mathrm{C}$. d) Ti O-PIII at $600^{\circ} \mathrm{C}(2000 \mathrm{x})$. Arrows: More evident cellular spreading and projection.

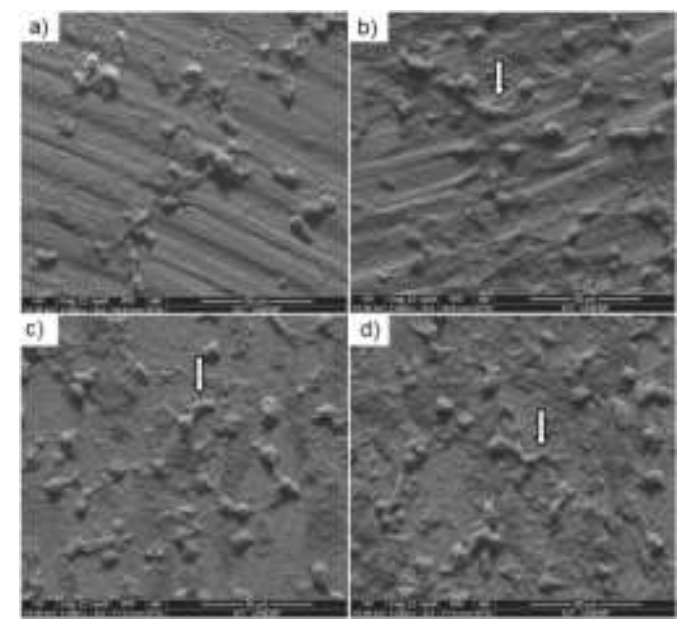

Source:Authors.

Concerning the cellular viability, no statistical difference is observed in Figure 8(a) among O-PIII Ti samples treated at $400^{\circ} \mathrm{C}$ and $500^{\circ} \mathrm{C}$ with the Ti group (pretreatment). However, MG-63 viability was statistically increased (p <0.05) in the group submitted to O-PIII treatment at $600^{\circ} \mathrm{C}$, compared to the other groups. Figure 8 also demonstrates that none of the Ti groups submitted to O-PIII treatment was statistically cytotoxic compared to the Ti group (pretreatment).

Concerning the total protein content, Figure 8 (b) demonstrates that groups submitted to O-PIII treatment at $400^{\circ} \mathrm{C}$ and $500^{\circ} \mathrm{C}$ had no alterations in protein expression when compared with the Ti group (pretreatment). However, O-PIII-treated Ti group at $600^{\circ} \mathrm{C}$ had protein expression statistically increased ( $\mathrm{p}<0.0001$ ), when compared to all groups.

After evaluating the surface characterization and MG-63 assays (Figure 1 to 8 ) carried out so far, O-PIII-treated group at $400^{\circ} \mathrm{C}$ was not considered for the following assays as it did not present significant results in the current study.

Concerning the alkaline phosphatase activity shown in Figure 8 (c), $\mathrm{Ti}$ (pretreatment) and O-PIII-treated $\mathrm{Ti}$ at $500^{\circ} \mathrm{C}$ groups did not present significant differences. However, the group submitted to O-PIII treatment at $600^{\circ} \mathrm{C}$ statistically increased $(\mathrm{p}<0.05)$ alkaline phosphatase activity when compared to the Ti group (pretreatment). No statistical changes were observed when compared to the O-PIII-treated Ti group at $500^{\circ} \mathrm{C}$.

According to Figure 8 (d), O-PIII-treated Ti group at $600^{\circ} \mathrm{C}$ had a statistical increase $(\mathrm{p}<0.0001)$ in the amount of mineralization nodules compared to $\mathrm{Ti}$ (pretreatment) and O-PIII-treated $\mathrm{Ti}$ group at $500^{\circ} \mathrm{C}$. However, $\mathrm{Ti}$ (pretreatment) group and O-PIII-treated Ti group at $500^{\circ} \mathrm{C}$ had no statistical difference when compared to each other. 
Figure 8 - Cellular analysis with the following groups: Ti, Ti O-PIII at $400^{\circ} \mathrm{C}$, Ti O-PIII at $500^{\circ} \mathrm{C}$ and $\mathrm{Ti} \mathrm{O}-\mathrm{PIII}$ at $600^{\circ} \mathrm{C}$. a) $\mathrm{Cell}$ Viability. b) Total protein content. c) Alkaline phosphatase activity. d) Quantification of mineralization nodules. $* * \mathrm{p}<0.05$ and $* * * * \mathrm{p}<0.0001$ compared to the $*$ (ANOVA and Tukey test). Asterisks indicates a statistical difference.
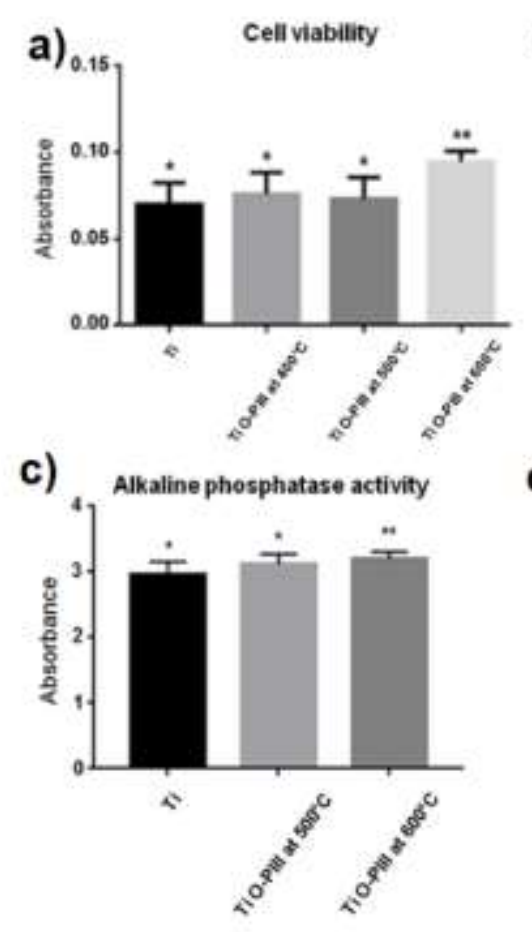

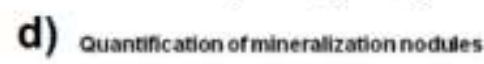
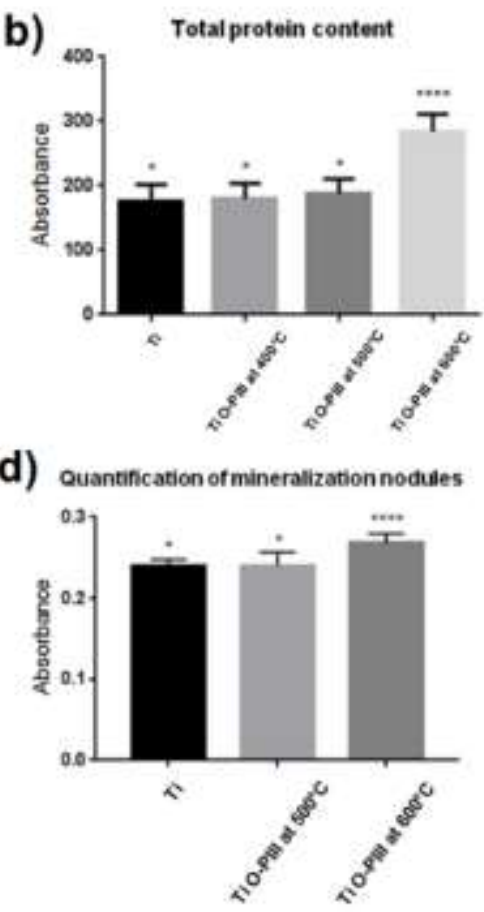

Source:Authors.

\subsection{Formation of Microbial Biofilms}

As observed in Figure 9 (a), in Ti (pretreatment) and O-PIII-treated Ti samples at $500^{\circ} \mathrm{C}$ and $600^{\circ} \mathrm{C}$, the monotypic biofilm formation of $\mathrm{P}$. aeruginosa was statistically decreased ( $\mathrm{p}<0.001, \mathrm{p}<0.001$ and $\mathrm{p}<0.00001$, respectively) compared to the control group. However, the group treated with $\mathrm{O}-\mathrm{PIII}$ at $600^{\circ} \mathrm{C}$ statistically decreased the amount of P. aeruginosa when compared to the O-PIII-treated group at $500^{\circ} \mathrm{C}$ and $\mathrm{Ti}$ (pretreatment).

In Figure 9 (b), only the group treated with O-PIII at $600^{\circ} \mathrm{C}$ presented a statistical decrease $(\mathrm{p}<0.001)$ compared to the control group, regarding monotypic biofilm formation of S. aureus. However, Ti (pretreatment) and O-PIII-treated Ti groups at $500^{\circ} \mathrm{C}$ and $600^{\circ} \mathrm{C}$ did not show significant changes in the amount of S. aureus when compared between themselves.

In Figure 9 (c), groups submitted to O-PIII treatment at $500^{\circ} \mathrm{C}$ and $600^{\circ} \mathrm{C}$ showed a statistical decrease $(\mathrm{p}<0.001)$ in the quantification of S. mutans, compared to Ti (pretreatment) and control groups, however, these groups had no alterations when compared to each other.

In Figure 9 (d), O-PIII-treated at $500^{\circ} \mathrm{C}$ and $600^{\circ} \mathrm{C}$ groups presented statistical decrease $(\mathrm{p}<0.001)$ in the amount of $C$. albicans compared to Ti (pretreatment) and control groups, however, these groups had no significant differences when compared to each other. 
Figure 9 - Quantification of monotypic microbial biofilms in the following groups: Control, $\mathrm{Ti}$, Ti O-PIII at 500 ${ }^{\circ} \mathrm{C}$ and $\mathrm{Ti} \mathrm{O}-$ PIII at $600^{\circ} \mathrm{C}$. a) P. aeruginosa. b) S. aureus. c) S. mutans. d) C. albicans. *** p <0.001 and **** p <0.0001 compared to the * (ANOVA and Tukey test). Asterisks indicates a statistical difference.
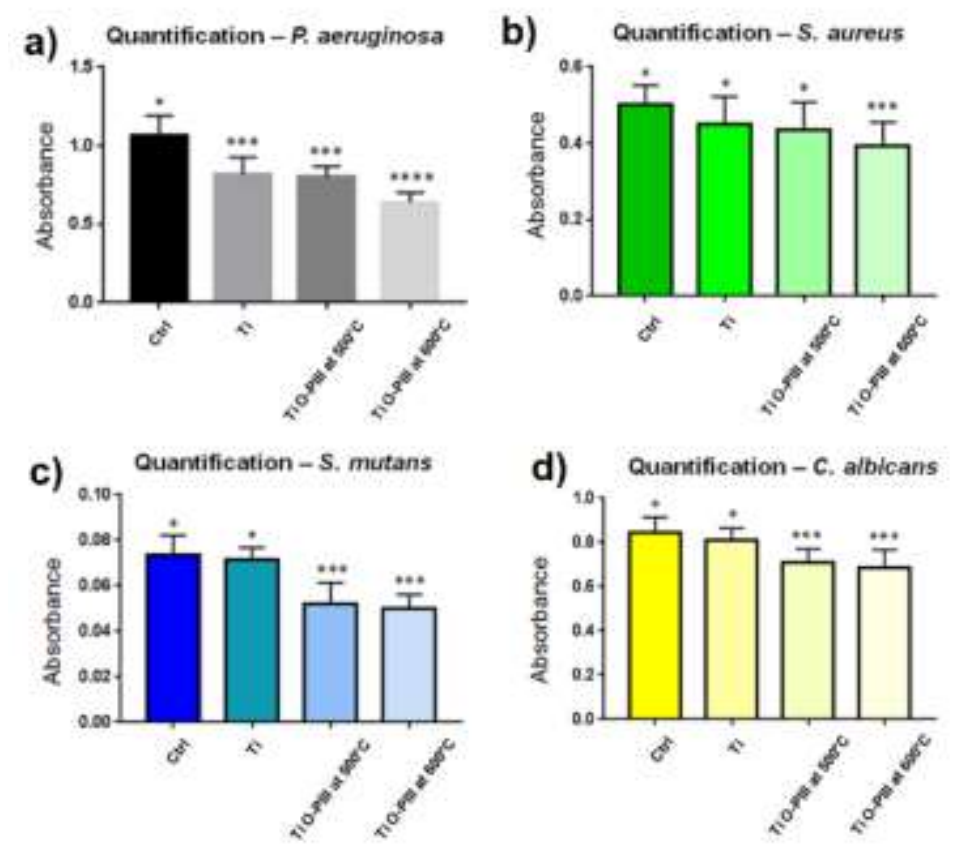

Source:Authors.

\section{Discussion}

Treatment with plasma immersion ion implantation (PIII) is responsible for modifying complex surfaces not altering sample size, moreover, it is possible to work with PIII in a wide temperature range, allowing the formation of structures and phases without balancing (Rossi et al., 2004, Gupta, 2011) .The advantages of PIII implantation system consist in the fact that the period of treatment do not depend on sample size and does not require special sample manipulation, even when surfaces are irregular (Ueda et al., 2007).

Atmospheric oxygen has strong affinity for Ti, forming a passive layer of oxide on its surface, which serves as a protective layer against corrosion. The thickness of this oxide layer may undergo some changes according to environmental conditions and treatment (Hansen et al., 2015). Recently, Mohan et al. (2017) evaluated chemical compositions of surface composed by $\mathrm{Ni}$, Ti and $\mathrm{O}$ on NiTi alloy substrates subjected to O-PIII technique. They observed an increase in oxygen percentage in the substrates of the studied alloys, and their spectra showed the presence of nickel, Ti and oxygen on these surfaces, indicating that enriching the surface with the oxygen treatment is essential for the formation of stoichiometric $\mathrm{TiO}_{2}$. These results corroborate our study, in which the formation of a greater amount of oxygen in the samples of Ti treated with $\mathrm{O}$ PIII at $400^{\circ} \mathrm{C}, 500^{\circ} \mathrm{C}$ and $600^{\circ} \mathrm{C}$ was observed. Moreover, we demonstrated that the higher the temperature used in the treatment, the higher the presence of oxygen on the surface.

The formation of rutile phase $\mathrm{TiO}_{2}$ after $\mathrm{Ti}$ treatment has recently been reported in the literature by several studies (Rafieian et al., 2015, Guan, \& Lou 2018, Sasahara et al., 2018). Yang et al. (2015) performed studies with the O-PIII treatment to create dense and thin layer of $\mathrm{TiO}_{2}$ on the surface of $\mathrm{Ti}$ for dental implants, they observed the formation of an oxide layer, mainly consisted of ruthenium $\mathrm{TiO}_{2}$. In our study, $\mathrm{TiO}_{2}$ (rutile phase) peaks observed in the groups treated with $\mathrm{O}-\mathrm{PIII}$ at $500^{\circ} \mathrm{C}$ and $600^{\circ} \mathrm{C}$, attested the efficacy of the treatment under these conditions, a consequence of the higher oxygen content. In contrast, Tóth et al. (2004) published that no crystalline oxide phase could be detected in TiAlV (titanium aluminum vanadium) alloy 
after oxidation. These authors suggested that treatment under low temperature and the presence of aluminum oxide may have prevented crystallization.

In this study, we observed that O-PIII-treated samples exhibited nanoporous surface structure, demonstrating a nanostructured $\mathrm{TiO}_{2}$ layer in the form of round grains, which is increased as the temperature increases in the treatment. The increase of the nanoscale roughness caused by O-PIII treatment had been previously reported (Hung et al., 2016, Wu et al., 2018). Hung et al. (2016) analyzed the morphology of Ti surfaces pre- and post-treated with O-PIII and, as in our results, Ti had relatively flat surfaces only with parallel polishing traces, however O-PIII-treated Ti showed nanoporous surface structure, exhibiting a more uniform, denser, nanostructured $\mathrm{TiO}_{2}$ layer, with higher round grain magnification compared to $\mathrm{Ti}$ (pretreatment) samples.

EIE is used for different purposes, ranging from electronic transport in semiconductor devices to the electrochemical kinetic processes of the most different natures, ie processes that occur in photovoltaic cells and corrosion systems (Bisquert et al., 2000, Gratzel, 2001). The measurement of corrosion resistance in this study showed that increasing surface treatment temperature resulted in greater inertia against corrosion in SBF medium. Consequently, the higher the temperature used in OPIII treatment, the higher the sample impedance. Pan et al. (1994) observed a dark pigmentation in Ti exposed for several weeks to phosphate buffered saline (PBS) with $\mathrm{H}_{2} \mathrm{O}_{2}$ additions, representing a suggestive point of corrosion caused by the treatment.

Recently, a range of studies involving cell analysis on Ti surfaces have been reported in the literature (Gehrke et al., 2018, Urenã et al., 2018, Kasnak et al., 2019) all of them designating Ti as a successful research tool, as cell interactions with the surface of the biomaterial can be evaluated in more detail. In our study, it was observed that all groups permitted cellular adhesion, moreover, O-PIII-treated samples had more evident cell adhered with more cellular projections. Soares et al. (2018) corroborate our results, describing that MG-63 cells also presented prolonged formats, surrounded by abundant cytoplasm, welldefined and intact when in contact with Ti.

Kiran et al. (2018) after evaluating the viability of MG-63 cells on different Ti surfaces, observed that all samples stimulated cell growth over a period, increasing viable cells; when samples were submitted to treatments with higher degree of morphological changes in the surfaces, a greater increase of cellular viability was described. Our results corroborate this previous study, showing a statistical increase in cell viability in Ti group submitted to O-PIII treatment at $600^{\circ} \mathrm{C}$, compared to the other groups.

Total protein content is an important parameter in osteogenesis. In this study, it was observed that the group submitted to the highest treatment temperature (Ti O-PIII at $600^{\circ} \mathrm{C}$ ) had a higher amount of proteins when compared to the other groups. Cheg et al. (2018) identified that surfaces treated with hydrothermal oxidation of low temperature microwaves promoted positive influence on MG-63 DNA content, but did not alter alkaline phosphatase and osteoprotegerin. However, in the present study, Ti submitted to treatment with O-PIII at $600^{\circ} \mathrm{C}$ increased alkaline phosphatase values.

A study conducted by Baranowski et al. (2016) allowed us to consider that the assay performed with Alizarin S Red dye revealed an increase in calcium deposition in osteoblast populations cultured with bone sialoprotein with morphogenetic bone protein additive 7 (BMP-7) compared to the control group with no additives (proliferation medium). Our results, which were also performed with Alizarin S Red dye, showed that Ti group treated with O-PIII at $600^{\circ} \mathrm{C}$ statistically increased the amount of mineralized matrix nodules compared to the other groups.

Ren et al. (2014) stated that cell culture assays clearly show that micro/nanotexturide surface of TiAlNb (titanium aluminum niobium) stimulates fixation, dissemination, proliferation and increased cell alkaline phosphatase activity better than polished surfaces. In our study, it was observed that the surface changes of O-PIII treated Ti samples at $600^{\circ} \mathrm{C}$ improved MG63properties, regarding adhesion, viability, protein expression, alkaline phosphatase activity and matrix mineralization. 
Decontaminating microorganisms and their toxins on implant surfaces consists in a prerequisite for preventing periimplantitis, in addition to achieving therapeutic success of implants. It has been shown that Gram-positive $S$. aureus bacteria have high affinity to titanium substrates, particularly to those with a rough surface finish (Aguayo et al., 2015, Izquierdo-Barba et al., 2015). Giannelli et al. (2016) observed the effects of laser diode on S. aureus biofilm adherent to Ti oxide surface of dental implants. They observed that this treatment in pulsed and continuous modes induced statistical reduction of viable cell compared to untreated biofilm. In the present study, only Ti group submitted to O-PIII treatment at $600^{\circ} \mathrm{C}$ statistically decreased cell viability compared to the control group, while the other groups did not demonstrate significant alterations in the quantification of S. aureus when compared between themselves. Although no statistical differences were observed, Ti and O-PIII-treated Ti at $500^{\circ} \mathrm{C}$ groups showed a trend to reduce cell viability.

Fatani et al. (2017) after evaluating orthodontic stainless-steel brackets coated with $\mathrm{TiO}_{2}$ as anti-adherent and antibacterial tool for Streptococcus mutans, observed a decrease in biofilm formation in brackets coated with $\mathrm{Ag}+\mathrm{TiO}{ }_{2}$ Our results demonstrated that $\mathrm{O}-\mathrm{PIII}$ treatment of $\mathrm{Ti}$ samples at $500^{\circ} \mathrm{C}$ and $600^{\circ} \mathrm{C}$ statistically reduced the amount of $\mathrm{S}$. mutans compared to Ti (pretreatment) and control groups.

Furthermore, we observed that, after one day of cultivation, the groups Ti and O-PIII-treated $\mathrm{Ti}$ at $500^{\circ} \mathrm{C}$ and $600^{\circ} \mathrm{C}$ showed a significant reduction of the quantification of $P$. aeruginosa in comparison with the control group. The group Ti O-PIII at $600^{\circ} \mathrm{C}$ was the one with higher significant decrease compared to the other groups. Studies carried out by Nunes Filho et al. (2018) stated that the chemical composition of Ti surface interferes with the biofilm formation of Pseudomonas aeruginosa. After quantifying the adhesion of bacteria in Ti and TiN samples, the authors observed that TiN showed higher performance against bacterial adhesion and aggregates formation, and that Ti (pretreatment), after the first $3 \mathrm{~h}$ of incubation, led to less than $20 \%$ of bacteria adhesion, while after $6 \mathrm{~h}$ this percentage increased. In TiN samples, after $3 \mathrm{~h}$, about $80 \%$ of the bacteria were adhered and, after a period of $6 \mathrm{~h}$ of exposure to nitride surfaces, bacteria were unable to bind. These results indicate a correlation between the chemical state of $\mathrm{Ti}$ and the interference observed in the first steps of $P$. aeruginosa biofilm formation. Jeyachandran et al. (2007) suggested that chemical status and roughness represent the main influences on the interaction of bacteria with the surface of an implant.

Previous studies have shown that Candida biofilms exhibit increased resistance to antifungal agents and, although several hypotheses have been suggested, none of them clearly elucidates the phenomenon of increased resistance. However, surface roughness has been shown to directly influence the adhesion of microorganisms to medical devices such as catheters and dental implants (Ramasay, \& Lee 2016, Vargas Blanco et al., 2017). In a study carried out by Tsang et al. (2007) about biofilms of Candida albicans on Ti plates with different roughness, it was observed that, from sandblasting with $99.6 \%$ aluminum oxide of different grain sizes, there was no statistically significant difference in fungal adherence between groups. In contrast, herein, we observed that Ti groups submitted to O-PIII treatment at $500^{\circ} \mathrm{C}$ and $600^{\circ} \mathrm{C}$ showed a statistical decrease in the quantification of C. albicans compared to $\mathrm{Ti}$ (pretreatment) and control groups.

\section{Conclusion}

O-PIII treatment in Ti samples at different temperatures $\left(400^{\circ} \mathrm{C}, 500^{\circ} \mathrm{C}\right.$ and $\left.600^{\circ} \mathrm{C}\right)$ promoted an increase in surface roughness, corrosion resistance, oxygen presence and formation of $\mathrm{TiO}_{2}$-rutile, as the temperature used in the treatment increased.

These modifications in surface properties resulted in MG-63 cells activity improvements when these cells are cultivated in contact with the materials, especially for O-PIII treatment at $600^{\circ} \mathrm{C}$. O-PIII treatment also reduced viability of monotypic microbial biofilms (P. aeruginosa, S. aureus, S. mutans and C. albicans), regardless of the temperature used in Ti treatment.

From these data obtained, it is suggested to use the O-PIII treatment at $600^{\circ} \mathrm{C}$ in $\mathrm{Ti}$ grade $\mathrm{IV}$, due to the increase in the 
substrate temperature during this technique, it is to facilitate the formation of the rutile phase, improving the physical-chemical properties of the samples treated. In addition, it presented good results in cell analysis, as well as a decrease in the quantification of monotypic microbial biofilms, becoming a promising material for clinical application. Thus, for future works is recommended in vivo studies to analyze the influence of Ti O-PIII treatment at $600^{\circ} \mathrm{C}$ in commercial implants both in bone neoformation, as in the biomechanical test, in order to evaluate the force fixation the osseointegration.

\section{Acknowledgments}

The authors thank the FAPESP (São Paulo State Research Foundation) for financial support for the scholarship (2017/21160-7).

\section{References}

Aguayo, S., Donos, N., Spratt, D., \& Bozec, L. (2015). Nanoadhesion of staphylococcus aureus onto titanium implant surfaces. Journal of dental research, 94, 1078-1084. https://doi.org/10.1177/0022034515591485

Andrade, D. P., Vasconcellos, L. M., Carvalho, I. C., Forte, L. F., Souza Santos, E. L.,\& Prado, R. F, et al.(2015) Titanium-35niobium alloy as a potential material for biomedical implants: In vitro study. Material science and engineer C, 56:538 444 . https://doi.org/10.1016/j.msec.2015.07.026

Baranowski, A., Klein, A., Ritz, U., Ackermann, A., Anthonissen, J., Kaufmann, K. B., Brendel, C., Götz, H., Rommens, P. M., \& Hofmann, A. (2016). Surface functionalization of orthopedic titanium implants with bone sialoprotein. PLoS one. https://doi.org/10.1371/journal.pone.0153978

Bisquert, J., Garcia-Belmonte, G., Fabregat-Santiago, F., Ferriols, N.S., Bogdanoff, P., \& Pereira, E.C. (2000). Doubling exponent models for the analysis of porous film electrodes by impedance: relaxation of $\mathrm{TiO}_{2}$ nanoporous in aqueous solution. The journal of physical chemistry B, 104 (10), 2287-2298. https://doi.org/10.1021/jp993148h

Cheng, A., Goodwin, W. B., de Glee, B. M., Gittens, R. A., Vernon, J. P., Hyzy, S. L., \& et al. (2018). Surface modification of bulk titanium substrates for biomedical applications via low-temperature microwave hydrothermal oxidation. Journal of biomedical materials research, 106, 782-796; https://doi.org/10.1002/jbm.a.36280

Da Silva, M. M., Ueda, M., Otani, C., Reuther, H., Lepienski, C. M., Junior, P. C. S., \& Otubo, J. (2006). Hybrid processing of Ti-6Al-4V using plasma immersion ion implantation combined with plasma nitriding. Materials Research, 9(1). https://doi.org/10.1590/S1516-14392006000100018

Do Prado, R. F., de Vasconcellos, L. G. O., de Vasconcellos, L. M. R., Cairo, C. A. A., Leite, D. O., dos Santos, A., Jorge. A. O., Romeiro. R. L., Balducci,I.,\& Carvalho,Y. R. (2013). In vivo osteogenesis and in vitro Streptococcus mutans adherence: porous-surfaced cylindrical implants vs rough-surfaced threaded implants. International journal oral maxillofacial implants, 28(6),1630-8. https://doi.org/10.11607/jomi.2747

do Prado, R. F., Esteves, G. C., Santos, E., Bueno, D., Cairo, C., Vasconcellos, L., Sagnori, R. S., Tessarin, F., Oliveira, F. E., Oliveira, L. D., Villaça-Carvalho, M., Henriques, V., Carvalho, Y. R., \& De Vasconcellos, L. (2018). In vitro and in vivo biological performance of porous Ti alloys prepared by powder metallurgy. PloS one, 13(5), e0196169. https://doi.org/10.1371/journal.pone.0196169

Fatani, E. J., Almutairi, H. A., Alharbi, A. O., Alnakhli, Y. O., Divakar, D. D., Muzaheed Alkheraif, A. A., \& Khan, A. A. (2017). In vitro assessment of stainless steel orthodontic brackets coated with titanium oxide mixed Ag for anti-adherent and antibacterial properties against Streptococcus mutans and Porphyromonas gingivalis. Microbial pathogenesis,112, 190-194. https://doi.org/10.1016/j.micpath.2017.09.052

Gehrke, S. A., Dedavid, B. A., Júnior, J. S. A., Pérez-Díaz, L., Guirado, J. L. C., Canales, P. M., \& De Aza, P. N. (2018). Effect of different morphology of titanium surface on the bone healing in defects filled only with blood clot: a new animal study design. BioMed research international, 9. https://doi.org/10.1155/2018/4265474

Giannelli, M., Landini, G., Materassi, F., Chellini, F., Antonelli, A., Tani, A., Zecchi-Orlandini, S., Rossolini, G. M., \& Bani, D.(2016). The effects of diode laser on Staphylococcus aureus biofilm and Escherichia coli lipopolysaccharide adherent to titanium oxide surface of dental implants: an in vitro study. Lasers in medical science, 31(8), 1613-1619. https://doi.org/10.1007/s10103-016-2025-5

Gimmel'farb, A. L., \& Abrarov, V. B. (1980). Opyt primeneniia konstruktsii iz titanovykh splavov v ortopedo-travmatologicheskoĭ klinike [Experience in the use of titanium alloy devices in an orthopedic traumatological clinic]. Meditsinskaia tekhnika, (3), 55-57.

Grätzel, M. (2001). Photoelectrochemical cells. Nature, 414, 338-344. https://doi.org/10.1038/35104607

Guan, B. Y., \& Lou, X. W. (2018). Asymmetric mesoporous rutile $\mathrm{TiO}_{2}$ microspheres with single crystal-like frameworks. Chemistry, (4),(10), 2264-2266. https://doi.org/10.1016/j.chempr.2018.09.023

Guglielmotti, M. B., Domingo, M. G., Steimetz, T., Ramos, E., Paparella, M. L., \& Olmedo, D. G. (2015). Migration of titanium dioxide microparticles and nanoparticles through the body and deposition in the gingiva: an experimental study in rats. European journal of oral sciences, $123(4), 242-248$. https://doi.org/10.1111/eos.12190

Gupta, D. (2011). Plasma immersion ion implantation (PIII) process: physics and technology. International Journal of Advancements in Technology, 2(4). 
Hansen, A. W., Beltrami, L. V. R., Antonini, L. M., Villarinho, D. J., das Neves, J. C. K., Marino, C. E. B., \& Malfatti, C.F. (2015). Oxide formation on NiTi surface: influence of the heat treatment time to achieve the shape memory. Materials Research, 18 (5). https://doi.org/10.1590/1516-1439.022415

Heringa, M. B., Peters, R., Bleys, R., van der Lee, M. K., Tromp, P. C., van Kesteren, P., van Eijkeren, J., Undas, A. K., Oomen, A. G., \& Bouwmeester, H. (2018). Detection of titanium particles in human liver and spleen and possible health implications. Particle and fibre toxicology, 15(1), 15. https://doi.org/10.1186/s12989-018-0251-7

Hung, W. C., Chang, F. M., Yang, T. S., Ou, K. L., Lin, C. T., \& Peng, P. W. (2016). Oxygen-implanted induced formation of oxide layer enhances blood compatibility on titanium for biomedical applications. Materials science and engineering: C. 68, 523-529. https://doi.org/10.1016/j.msec.2016.06.024

Izquierdo-Barba, I., García-Martín, J. M., Álvarez, R., Palmero, A., Esteban, J., Pérez-Jorge, C., Arcos, D., \& Vallet-Regí, M. (2015). Nanocolumnar coatings with selective behavior towards osteoblast and Staphylococcus aureus proliferation. Acta Biomaterialia ,15, 20-28. https://doi.org/10.1016/j.actbio.2014.12.023

Jeyachandran, Y. L., Venkatachalam, S., Karunagaran, B., Narayandass, S. K., Mangalaraj, D., Bao, C. Y., \& Zhang, C. L. (2007). Bacterial adhesion studies on titanium, titanium nitride and modified hydroxyapatite thin films. Materials science and engineering C, 35-41. https://doi.org/10.1016/j.msec.2006.01.004

Kasnak, G., Fteita, D., Jaatinen, O., Könönen, E., Tunali, M., Gürsoy, M., \& Gürsoy, U. K. (2019) Regulatory effects of PRF and titanium surfaces on cellular adhesion, spread, and cytokine expressions of gingival keratinocytes. Histochemistry and Cell Biology, 1-11. https://doi.org/10.1007/s00418-019-01774-8

Kiran, A. S. K., Kumar, T. S. S., Perumal, G., Sanghavi, R., Doble, M., \& Ramakrishna, S. (2018). Dual nanofibrous bioactive coating and antimicrobial surface treatment for infection resistant titanium implants. Progress in organic coatings, 121, 112-119. https://doi.org/10.1016/j.porgcoat.2018.04.028

Kohavi, D., Badihi, L., Rosen, G., Steinberg, D., \& Sela, M. N. (2013). An in vivo method for measuring the adsorption of plasma proteins to titanium in humans Biofouling, 29(10), 1215-1224. https://doi.org/10.1080/08927014.2013.834332

Lowry, O. H., Rosebrough, N. J., Farr, A. L., \& Randall, R. J. (1951). Protein measurement with the folin phenol reagent. The Journal of Biological Chemistry, 193(1), 265-275

Mandl, S., Krause, D., Thorwarth, G., Sader, R., Zeilhofer, F., Horch, H. H., \& Rauschenbach, G. (2001). Biocompatibility of titanium based implants treated with plasma immersion ion implantation. Surface and coatings technology, 142, 1046-1050.https://doi.org/10.1016/S0168-583X(03)00813-9

Mandl, S., Sader, R., Thorwarth, G., Krause, D., Zeilhofer, H. F., Horch, H. H., \& Rauschenbach, B. (2002). Investigation on plasma immersion ion implantation treated medical implants. Biomolecular Engineering, 19, 129-132.https://doi.org/10.1016/S1389-0344(02)00025-4

Mello, D. C. R., de Oliveira, J. R., Cairo, C. A. A., Ramos, L. S. B., Vegian, M. R. C., de Vasconcellos, L. G. O., de Oliveira, F. E., de Oliveira, L. D., de Vasconcellos, L. M. R. (2019). Titanium alloys: in vitro biological analyzes on biofilm formation, biocompatibility, cell differentiation to induce bone formation, and immunological response. Journal of Materials Science: Materials in Medicine, 30(9), 108.httpp://doi.org.10.1007/s10856-019-6310-2

Mohan, L., Chakraborty, M., Viswanathan, S., Mandal, C., Bera, P., Aruna, S.T., \& Anandana, C. (2017). Corrosion, wear, and cell culture studies of oxygen ion implanted Ni-Ti alloy. Surface interface analysis, 49, 828-836. https://doi.org/10.1002/sia.6229.

Morais, M. N., Silveira,W. C., Teixeira, L. E. M., \& Araújo, I. D.(2013). Mechanisms of bacterial adhesion to biomaterials. Revista de medicina de Minas Gerais, 23(1), 96-101. https://doi.org/ 10.5935/2238-3182.20130015

Munoz-Castro, A. E., Lopez-Callejas, R., Granda- Gutierrez, E. E., Valencia-Alvarado, R., Barocio, S. R., Pena-Eguiluz, R., Mercado-Cabrera, A., \& De la Piedad Beneitez, A. (2009). Ion implantation of oxygen and nitrogen in cpti. Progress in Organic Coatings, 64, 259263.https://doi.org/10.1016/j.porgcoat.2008.08.021

Nunes Filho, A., Aires, M. M., Braz, D. C., Hinrichs, R., Macedo, A. J., \& Alves, C. Jr. (2018). Titanium surface chemical composition interferes in the pseudomonas aeruginosa biofilm formation. Artificial organs, 42(2),1991193-1992018. https://doi.org/doi:10.1111/aor.12983

Oliveira, R. M., Gonçalves, J. A. N., Ueda, M., Rossi, J. O., \& Rizzo, P. N. (2010). A new high-temperature plasma immersion ion implantation system with electron heating. Surface and coatings technology, 22(6), 3009-3012. https://doi.org/10.1016/j.surfcoat.2010.03.014

Oliveira, R. M., Mello, C. B., Silva, G., Golçalves, J. A. N., Ueda, M., \& Pichon, L. (2011). Improved properties of Ti6Al4V by means of nitrogen high temperature plasma based ion implantation. Surface and coatings technology, 205, S111-S114. https://doi:10.1016/j.surfcoat.2011.03.029

Pan, J., Thierry, D., \& Leygraf, C. (1994). Electrochemical and XPS studies of titanium for biomaterial applications with respect to the effect of hydrogen peroxide. Journal of biomedical materials research, 28(1), 113-122. https://doi.org/10.1002/jbm.820280115

Peláez-Abellán, E., Duarte, L. T., Biaggio, S. R., Rocha-Filho, R. C., \& Bocchi, N. (2012). Modification of the titanium oxide morphology and composition by a combined chemical-electrochemical treatment on cp Ti. Materials Research, 15(1). São Carlos. https://doi.org/10.1590/S1516-14392012005000002

Rafieian, D., Ogieglo, O., Savenije, T., \& Lammertink, R.G.H. (2015). Controlled formation of anatase and rutile TiO 2 thin films by reactive magnetron sputtering. AIP Advances, 5(9),097168. https://doi.org/10.1063/1.4931925

Ramasamy, M., \& Lee, J. (2016). Recent nanotechnology approaches for prevention and treatment of biofilm-associated infections on medical devices. BioMed Research International. https://doi.org/10.1155/2016/1851242

Ren, N., Zhang, S., Li, Y., Shen, S., Niu, Q., Zhao, Y., \& Kong, L. (2014). Bone mesenchymal stem cell functions on the hierarchical micro/nanotopographies of the Ti-6Al-7Nb alloy. British journal of oral and maxillofacial surgery, 52(10), 907-912. https://doi.org/10.1016/j.bjoms.2014.08.022

Rossi, J. O., Ueda, M., \& Barroso, J. J. (2004). Pulsed power modulators for surface treatment by plasma immersion ion implantation. Brazilian Journal of Physics, 34(4b), 1565-1571. https://doi.org/10.1590/S0103-97332004000800011 
Sasahara, A., Murakami,T., \& Tomitori, M. (2018). Dependence of calcium phosphate formation on nanostructure of rutile $\mathrm{TiO}_{2}(110)$ surfaces. Japanese journal of applied physics, 57(11). https://doi.org/10.1021/acs.jpcc.6b05661

Savonov, G. S., Ueda, M., Oliveira, R. M., \& Otani, C. (2011). Electrochemical behavior of the Ti6Al4V alloy implanted by nitrogen PIII. Surface and coatings technology, 206, 2017-2020. https://doi:10.1016/j.surfcoat.2011.09.007

Sidambe, A.T. (2014). Biocompatibility of advanced manufactured titanium implants: a review. Materials, vol (7), pages 8168-8188. ISSN 1996-1944. https:// doi.org/10.3390/ma7128168

Soares,T. P., Garcia, C. S. C., Roesch-Ely, M., da Costa, M. E. H. M., Aguzzoli, C., \& Giovanela, M. (2018). Cytotoxicity and antibacterial efficacy of silver deposited onto titanium plates by low-energy ion implantation. Journal of materials research, 33(17). https://doi.org/10.1557/jmr.2018.200

Thelen, S., Barthelat, F., \& Brinson, L. C. (2004). Mechanics considerations for microporous titanium as an orthopedic implant material. Journal of biomedical materials research. Part A, 69(4), 601-610. https://doi.org/10.1002/jbm.a.20100

Tóth, A., Mohai, M., Ujvári, T., Bell, T., Dong, H., \& Bertóti, I. (2004). Surface chemical and nanomechanical aspects of air PIII-treated Ti and Ti-alloy. Surface and coatings technology, 186 (1), 248-254.https://doi.org/10.1016/j.surfcoat.2004.04.031

Tsang, C. S., Ng, H., \& McMillan, A.S. (2007). Antifungal susceptibility of Candida albicans biofilms on titanium discs with different surface roughness. Clinical oral investigations, 11(4),361-368. https://doi.org/10.1007/s00784-007-0122-3

Ueda, M., Silva, M. M., Lepienski, C. M., Soares, P. C., Gonçalves, J. N., \& Reuther, H. (2007). High temperature plasma immersion ion implantation of Ti6Al4V. Surface and coatings technology, 201, 4953-56. https://doi.org/10.1016/j.surfcoat.2006.07.074

Ureña, J., Tsipas, S., Jiménez-Morales, A., Gordo, E., Detsch, R., Boccaccini, A.nR. (2018). Cellular behaviour of bone marrow stromal cells on modified Ti$\mathrm{Nb}$ surfaces. Materials and design, 140, 452-59. https://doi.org/10.1016/j.matdes.2017.12.006

Valencia-Alvarado, R., Lopez-Callejas, R., Barocio, S. R., Mercado-Cabrera, A., Pena-Eguiluz, R., Munoz-Castro, A. E., De la Piedad-Beneitez, A., \& De la Rosa-Vazquez, J. M. (2010). $\mathrm{TiO}_{2}$ films in the rutile and anatase phases produced by inductively coupled rf plasmas. Surface and coatings technology, 204, 3078-3081.https://doi.org/10.1016/j.surfcoat.2010.02.059

Vargas-Blanco, D., Lynn, A., Rosch, J., Noreldin, R., Salerni, A., Lambert, C., \& Rao, R. P. (2017). A pre-therapeutic coating for medical devices that prevents the attachment of Candida albicans. Annals of clinical microbiology and antimicrobials, 16-41. https://doi.org/10.1186/s12941-017-0215-z

Wu, S., Altenried, S., Zogg, A., Zuber, F., Maniura-Weber, K., \& Ren, Q. (2018). Role of the surface nanoscale roughness of stainless steel on bacterial adhesion and microcolony formation. ACS Omega, 3 (6), 6456-6464. https://doi.org/10.1021/acsomega.8b00769.

Xiao, Y., Wu, J., Yue, G., Reuther, H., \& Lin J. (2012). The surface treatment of Ti meshes for use in large-area flexible dye-sensitized solar cells. Journal of power sources, 208, 197-202. https://doi.org/10.1016/j.jpowsour.2012.02.019

Yamagami, A., Nagaoka, N., Yoshihara, K., Nakamura, M., Shirai, H., Matsumoto, T., Suzuki, K., \& Yoshida, Y. (2014). Ultra-structural evaluation of an anodic oxidated titanium dental implant. Dental materials journal, 33(6), 828-834. https://doi.org/10.4012/dmj.2014-121

Yang, C. H., Li, Y. C., Tsai, W. F., Ai, C. F., Huang, H. H. (2015). Oxygen plasma immersion ion implantation treatment enhances the human bone marrow mesenchymal stem cells responses to titanium surface for dental implant application. Clinical oral implants research, 26, 166175.https://doi.org/10.1111/clr.12293

Zaatreh, S., Wegner, K., Strauß, M., Pasold, J., Mittelmeier, W., Podbielski, A., Kreikemeyer, B., \& Bader, R. (2016). Co-Culture of S. epidermidis and human osteoblasts on implant surfaces: an advanced in vitro model for implant-associated infections. PLoS one, 11(3), e0151534. https://doi.org/10.1371/journal.pone.0151534

Zhao, B., Van der Mei, H. C., Rustema-Abbing, M., Busscher, H. J., \& Ren, Y. (2015). Osteoblast integration of dental implant materials after challenge by subgingival pathogens: a co-culture study in vitro. International journal oral science. $\mathrm{https}: / / \mathrm{doi} .0 \mathrm{rg} / 10.1038 / \mathrm{ijos} .2015 .45$ 